\title{
The Mapping of the Soils' Degradation State by Adaptation the PAP/RAC Guidelines in the Watershed of Wadi Arbaa Ayacha, Western Rif, Morocco
}

\author{
Abdessalam Ouallali ${ }^{*}$, Mohamed Moukhchane ${ }^{2}$, Habiba Aassoumi1 ${ }^{1}$ Farida Berrad ${ }^{3}$, \\ Ibrahim Dakir ${ }^{1}$ \\ ${ }^{1}$ Department of Geology, Faculty of Science, Abdelmalek Essaadi University, Tetouan, Morocco \\ ${ }^{2}$ Department of Earth Sciences, Abdelmalek Essaadi University, Ecole Normale Supérieure, Martil, Morocco \\ ${ }^{3}$ Regional Directorate of Forestry and Fight against Desertification of Rif, Tetouan, Morocco \\ Email: "abdessalam.ouallali@gmail.com
}

Received 16 May 2016; accepted 22 July 2016; published 25 July 2016

Copyright (C) 2016 by authors and Scientific Research Publishing Inc. This work is licensed under the Creative Commons Attribution International License (CC BY). http://creativecommons.org/licenses/by/4.0/

(c) (i) Open Access

\section{Abstract}

The watershed of the Arbaa Ayacha River is an environment favorable to the development of the phenomena of water erosion as a result of its topographic features, lithological and climate. Therefore it has been the subject of evaluation of states erosive and of different causal factors of the risk of erosion by adaptation of cross-matrices based on directives PAP/RAC (Priority Actions Programme/Regional Activity Centre) [1]. This method is based on three approaches. The predictive approach provides a synthetic map of the distribution of the erosive states, with $51 \%$ of the basin subjected to high risks. The descriptive mapping of the various forms of erosion shows an enormous extension of stripping and sheet erosion (91\%), superficial gullies and moderately deep gullies are growing in view of the gathering of runoffs from upstream to the downstream. The superposition of the results of both predictive and descriptive approaches gives a consolidated map PAP/RAC whose analysis shows that soils' loss throughout the basin is proportional to the increase of the major factors of water erosion according to the level of importance: The topographical factor-soil types-slope-lithology following a positive linear relationship, while the order of the parameters that are negative linear relationship is density of vegetation cover-land cover [2]. This same map gives maximal losses corresponding mainly to friable lithologic natural areas of badlands at the center of the basin which correspond to Tensift's terraces [3]. In the downstream

${ }^{*}$ Corresponding author.

How to cite this paper: Ouallali, A., Moukhchane, M., Aassoumi, H., Berrad, F. and Dakir, I. (2016) The Mapping of the Soils' Degradation State by Adaptation the PAP/RAC Guidelines in the Watershed of Wadi Arbaa Ayacha, Western Rif, Morocco. Journal of Geoscience and Environment Protection, 4, 77-88. http://dx.doi.org/10.4236/gep.2016.47009 
basin, the combined effect of deep ravines and banks sapements promotes high risk while in the upstream, the localized solifluxions and gravity screens participate in serious losses.

\title{
Keywords
}

\author{
Water Erosion, PAP/RAC, Arbaa Ayacha, Western Rif, Morocco
}

\section{Introduction}

The watershed Arbaa Ayacha $\left(199.9 \mathrm{~km}^{2}\right)$ has the same climatic characteristics of the western Rif which has a huge extension of cultivated land, and a very small area of dense vegetation; which makes it more vulnerable to the risk of water erosion. Hence the need to develop a strategy in the basin in the near future, as will there be an infrastructure development during the installation of the new dam projected Arbaa Ayacha [4]. In fact this area is characterized by heavy and aggressive rains, with friable lithological formations such as marl, the calcareous marls and shales [5] on very high slopes. The effect of these threats appears especially in the downstream of watersheds by reducing the capabilities of water infrastructure retention, and by leaching the fine fractions and nutrients of farmland by sheet erosion. The impacts of these phenomena negatively affect the country's economy, especially Morocco that is economically based on agriculture and water resources. Faced with these threats, the assessment of water erosion and stabilization of land becomes a necessity. And with the development of new spatial techniques such as GIS and remote sensing, the mapping areas vulnerable to water erosion are becoming more efficient. Several methods and models are developed, and among these models, the PAP/RAC (Priority Actions Programme/Regional Activity Centre) guidelines are the most suited to the Mediterranean conditions. The application of this model in other watersheds of the Moroccan territory, to know the watershed of the Wadi Larbaa [6], Allal El Fasi [7], Sahla [8] and Asfalou River [9] shows the reliability of this model applied.

The catchment area of the river Arbaa Ayacha is not protected against this phenomenon. It is an environment which is ideal for the spread of risks and forms of water erosion, hence the need for qualitative and quantitative evaluation of soil losses. Adapting the PAP/RAC guidelines in this basin is a basic step to planners and decision makers in this area which will know the construction of the proposed dam of Arbaa Ayacha.

\section{Study Area}

The area of watershed of Arbaa Ayacha with $199.9 \mathrm{Km}^{2}$ is characterized by a sub-humid Mediterranean climate with mild winters; it is located in the north of the province of Larache and the south of the province of TangerAssilah (Figure 1) it is intersected by Highways that connect Larache and Tetouan. The location map shows the area that includes the administrative boundaries of four rural towns that are the subject of our study: Lkhaloua, BniGargatt, Sidi El yamani and Arbaa Ayacha.

Topographically, this watershed has a modest altitudinal variation which goes from varies from $6 \mathrm{~m}$ in outlet to $549 \mathrm{~m}$ on the highest peak. The major part is located above $50 \mathrm{~m}$ in altitude and the hypsometry shows two slices of altitudes $(50,100),(100,150)$ occupying $64 \%$ of surface and reflecting the hilly nature of the basin. The lower elevations extend over the downstream part and occupy $18 \%$ of surface while the higher ones are located in the far southwestern basin and do not exceed $4 \%$.

The geomorphological map of the peninsula of Tangier developed by El Gharbaoui [3], which is part of the study of humans and earth in Tingitane peninsula, shows that this site mainly consists of Cretaceous marl of Habt in the basin center occupying 53.52\% of the area. This place has Oligomiocene sandstones of Habt, white marl Eocene flint of Habt, Soltano-Rharbien Tensiftians benches and terraces. These units respectively occupy (6.70\%), (4.66\%), (3.84\%) and (5.65\%) of the total area of the watershed. In the upstream of this area, there are sandstone and Numidian Aquitanian occupying 4.91\% and marl and limestone-shale of the unit of Tangier (8.70\% by area) while the downstream basin has mainly some accumulations of predominantly sandy Villafranchian age and occupies (10.25\%) of the area of the basin.

\section{Methodology}

The mapping and measurement of rainfall-induced erosion processes in the Mediterranean coastal areas carried 


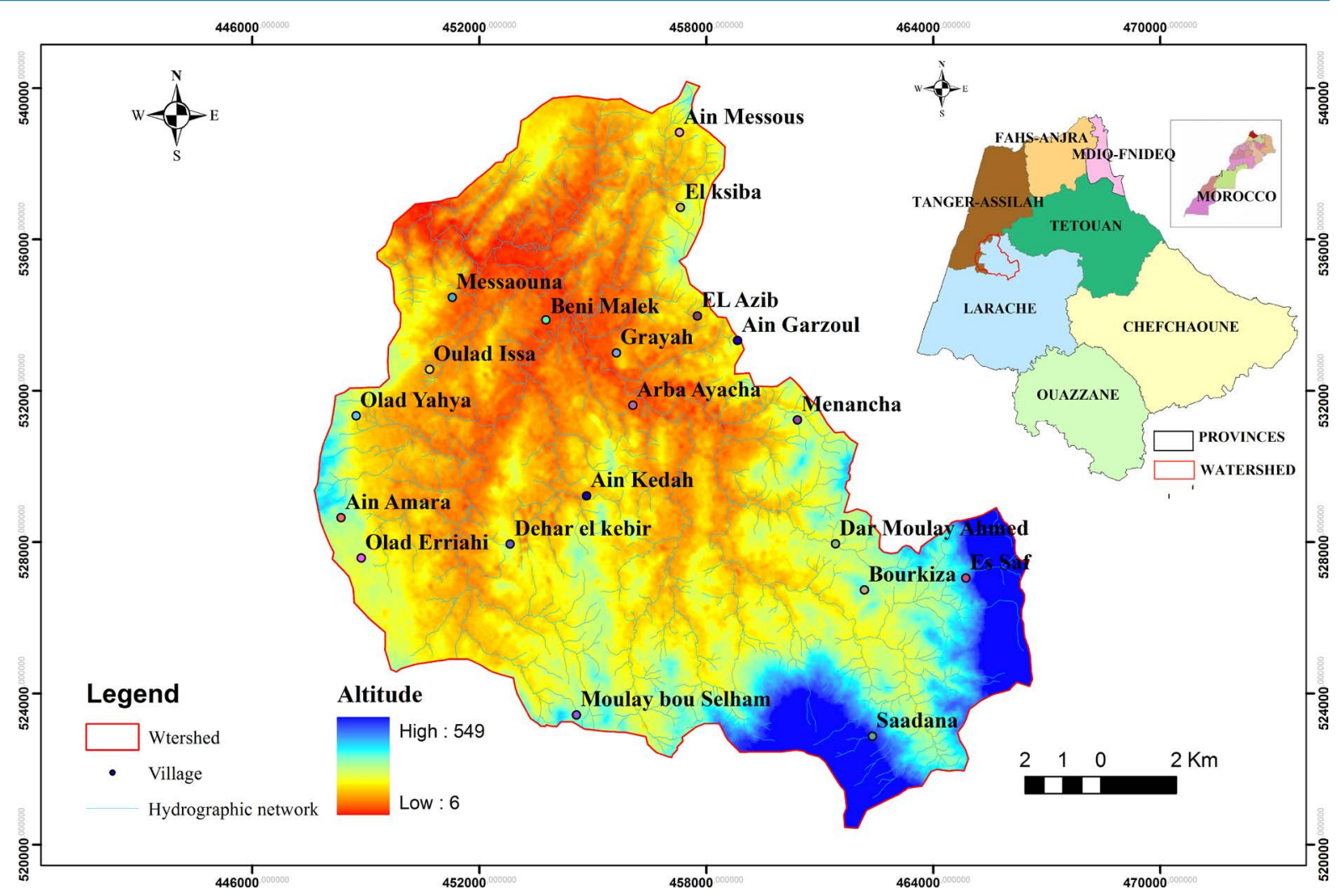

Figure 1. Location and elevation map of the watershed Aarbaa Ayacha.

out by a number of institutions such as the UNEP, FAO and DGCONA lead to the development of the PAP/ RAC methods which includes three methodological approaches of mapping, evaluating and estimating water erosion.

- The predictive approach gives values to the causal factors to the outbreak of water erosion (slope, lithology and/or soil type, land cover and vegetation density). The result of this phase allows to prioritize the basin according to the degree of erosion and to have a map of erosive state.

- The descriptive approach corresponds to the cartography on site of erosion forms and their exposure to erosion. It is particularly interested in the qualitative aspect of water erosion.

- The approach of integration is the end result of the two previous approaches, by superimposing the map of erosion forms to those of the erosion states. It provides a consolidated synthetical map of water erosion.

(Figure 2) shows the methodological scheme for the application of the PAP/RAC guidelines in the watershed of Wadi Arbaa Ayacha.

\section{Results and Discussion}

\subsection{Predictive Approach}

This approach is based on the interaction and the interdependence of the major factors of water erosion. In the first step, the superimposing of the slopes' map and the soil provides an erodibility map. The density of vegetation and the land use permit secondly to have a map of soil protection while the superposition of the two previous provides a synthetic map of erosion states and therefore the degree of erosion soils.

\subsubsection{Achieving Erodibilty Map of Soils}

The slopes' map was made by operating a DTM (digital terrain model) of resolution of $25 \mathrm{~m}$; this map was classified into five classes according to the classification adopted by the PAP/RAC method. Table 1 shows the predominance of class (3 - 12) which occupies (44\%) of the area of the basin followed by the (12 - 20) class that occupies (31\%). The maximum values of the slopes are located largely in the south-west part of the basin, in the 


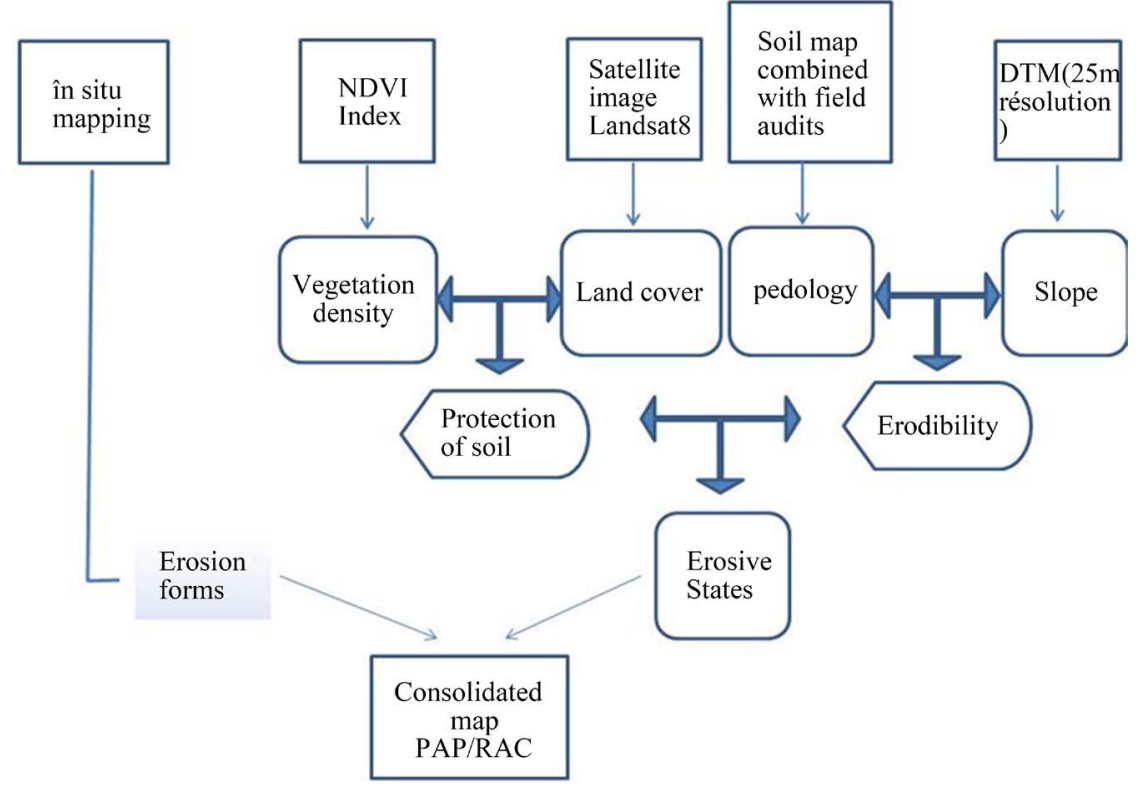

Figure 2. Methodological flowchart of the application of the method PAP/RAC.

Table 1. Percentage of classes’ slopes.

\begin{tabular}{ccc}
\hline Slope classes & Area in $\left(\mathrm{Km}^{2}\right)$ & Percentage $(\%)$ \\
$0-3$ & 11.05 & $6 \%$ \\
$3-12$ & 87.69 & $44 \%$ \\
$12-20$ & 61.02 & $31 \%$ \\
$20-35$ & 34.80 & $17 \%$ \\
$35-86$ & 4.44 & $2 \%$ \\
\hline
\end{tabular}

central part of the basin in the minority on the Tensiftiannes terraces with medium altitudes and towards the south at the boundaries of the watershed.

The soil map was established referring to the soil map prepared by Inypsa [10]. As part of the integrated project of agricultural development in Tangier-Tetouan, supplemented by field audits and based on the soil map of the area of Tangier which was established by Alami (in Osrirhi) [11]. The classification of this map was made by adapting the PAP/RAC guidelines and the degree of the soils' erodibilty. The superposition of two thematic maps under the ArcGIS device after being codified according to matrices adopted by the PAP/RAC guidelines method (Table 2) allows a degree of erodibilty map of soils in the intended area (Figure 3).

The analysis of this map shows that $45 \%$ of the basin area has a low or moderate erodibility (Figure 4 ) and is located to the center of the basin at the alluvial plain on gentle slopes except in a few places that always correspond to Tensiftian terraces of average altitude and unsophisticated soil susceptible to erosion. The average erodibilty values represent 30\% in surface and appear generally in the northwest while the values of strong erodibility are located predominantly in the southwest part of the basin and occupy $26 \%$ of the total watershed area.

\subsubsection{Achieving the Map of Soil Protection}

This step is based on the exploitation of remote sensing data and integrates the results into the GIS (Geographic information system) to assess the distribution of the degree of soil protection of that watershed. Indeed, a Landsat 8 satellite image dated in 2015 and downloaded at USGS, underwent a treatment and a supervised classification by field visits in order to map the different types of land tenure. The result shows that $69 \%$ of the study area corresponds to dry and/or herbaceous farming land while forests only cover less than $1 \%$ of the total area of the basin. This same image was purpose of the calculating NDVI (Normalized Difference Vegetation Index) which is an index to estimate the density of the vegetation in the study site, by adapting the Equation (1) [12]:

$$
\text { Cover }(\%)=-4337-3733 * \mathrm{NDVI}+161,968 * \mathrm{NDVI}^{2}
$$


Table 2. Matrix slope- soil.

\begin{tabular}{cccccc}
\hline \multirow{2}{*}{ Slope classes } & \multicolumn{5}{c}{ Soil classes } \\
\cline { 2 - 5 } & $1(\mathrm{a})$ & $2(\mathrm{~b})$ & $3(\mathrm{c})$ & $4(\mathrm{~d})$ & $5(\mathrm{e})$ \\
\hline 1 & $1(\mathrm{EN})$ & $1(\mathrm{EN})$ & $1(\mathrm{EN})$ & $1(\mathrm{EN})$ & $2(\mathrm{~EB})$ \\
2 & $1(\mathrm{EN})$ & $1(\mathrm{EN})$ & $2(\mathrm{~EB})$ & $3(\mathrm{EM})$ & $3(\mathrm{EM})$ \\
3 & $2(\mathrm{~EB})$ & $2(\mathrm{~EB})$ & $3(\mathrm{EM})$ & $4(\mathrm{EA})$ & $4(\mathrm{EA})$ \\
4 & $3(\mathrm{EM})$ & $3(\mathrm{EM})$ & $4(\mathrm{EA})$ & $5(\mathrm{EX})$ & $5(\mathrm{EX})$ \\
5 & $4(\mathrm{EA})$ & $4(\mathrm{EA})$ & $5(\mathrm{EX})$ & $5(\mathrm{EX})$ & $5(\mathrm{EX})$ \\
\hline
\end{tabular}

Legend: 1 (low EN), 2 (moderate EB), 3 (average EM), 4 (forte EA), 5 (extreme EX).

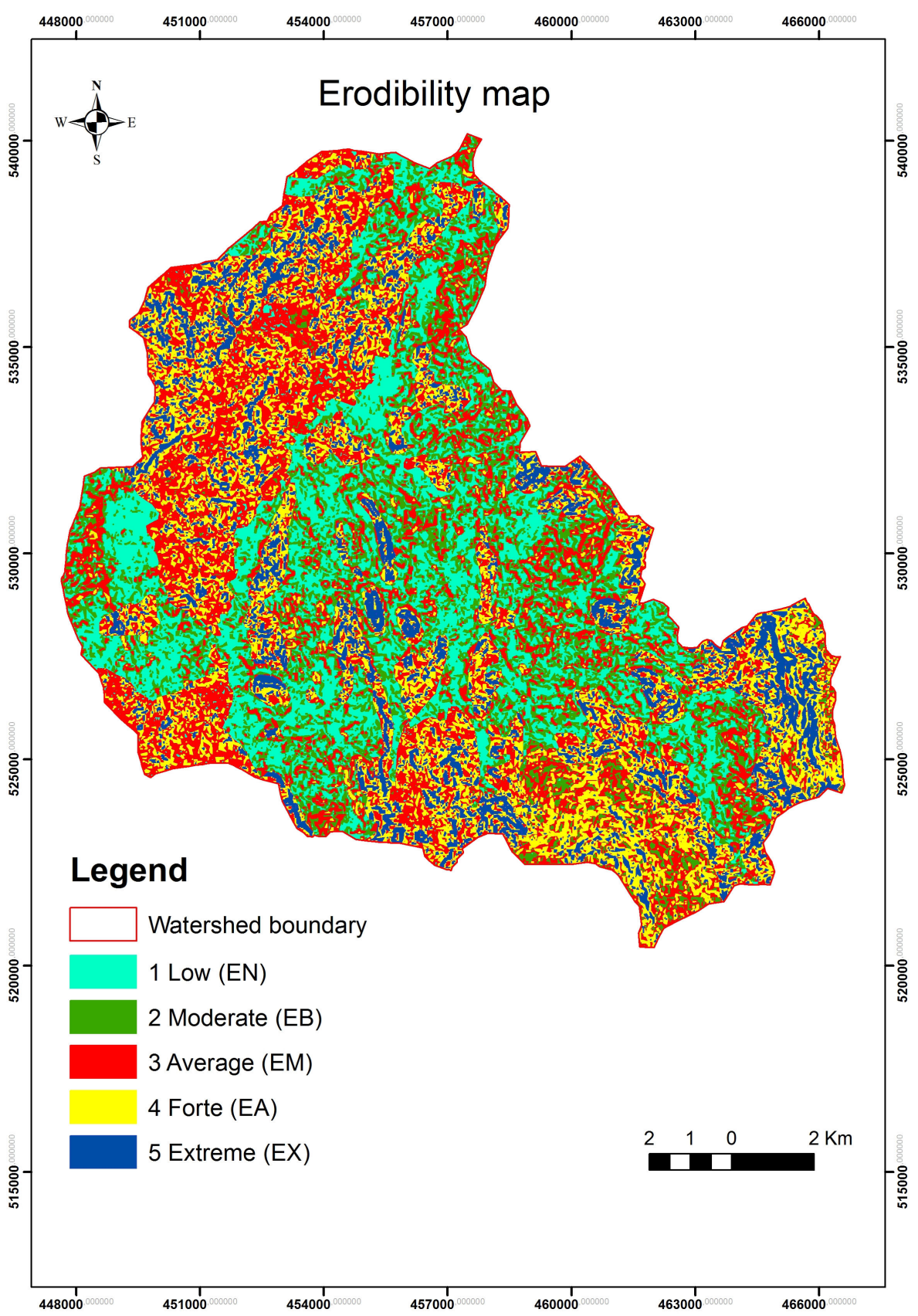

Figure 3. Erodibility map. 
The result shows that $83.04 \%$ of the basin area belongs to the class $(0-25)$, and the coding adopted by the PAP/RAC guidelines to land cover and land use (Table 3 ) and their superposition provides a degree of distribution map of soil protection (Figure 5). The analysis of the latter shows that $89.54 \%$ of the watershed is very weakly protected while the average or very high degree of protection is only 6.68\% (Table 4).

\subsubsection{Elaboration of the Map of the Erosive-States}

The map of the erosive states characterizes the vulnerability of the watershed to erosion, which is the result of the superposition of the erodibilty map and the soil protection (coded according to the matrix of the PAP/RAC guidelines, (Table 5). It allows prioritizing the watershed in units of the same erosive process. The processing

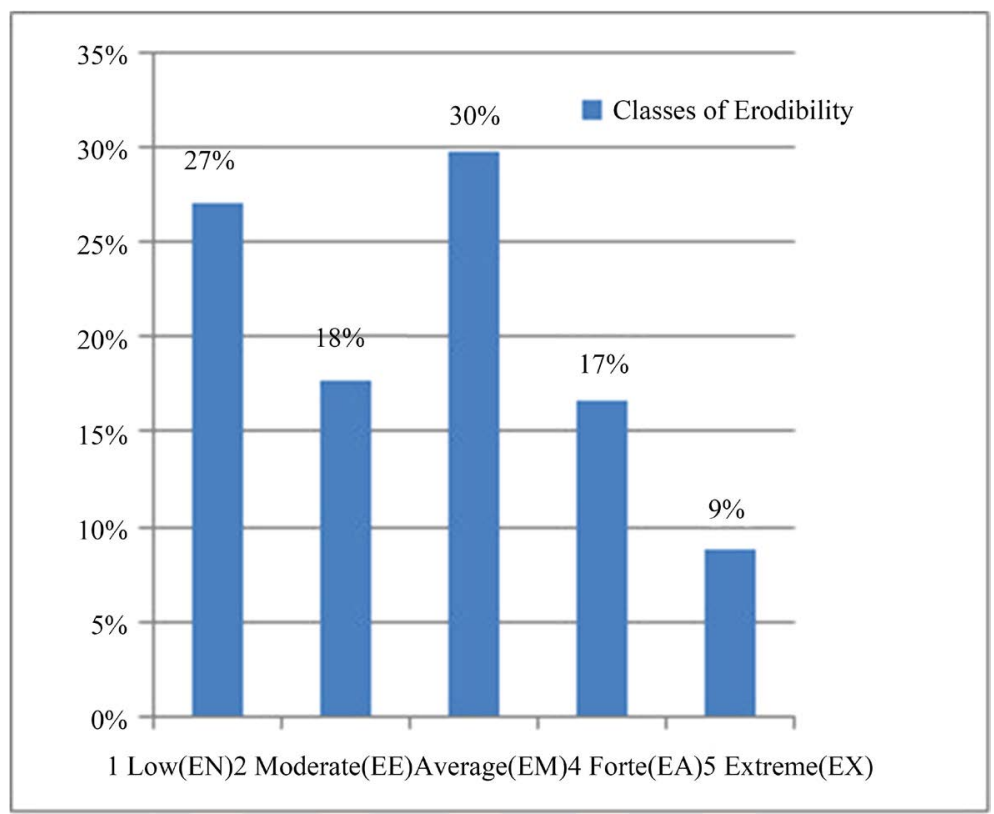

Figure 4. Classes percentage of erodibility.

Table 3. Matrix land cover-vegetation.

\begin{tabular}{cccc}
\hline \multirow{2}{*}{ Land cover } & \multicolumn{3}{c}{ Vegetation density } \\
\cline { 2 - 4 } & 1 & 2 & 3 \\
\hline 1 & $5(\mathrm{MB})$ & $5(\mathrm{MB})$ & $4(\mathrm{~B})$ \\
2 & $5(\mathrm{MB})$ & $5(\mathrm{MB})$ & $4(\mathrm{~B})$ \\
3 & $3(\mathrm{M})$ & $2(\mathrm{~A})$ & $1(\mathrm{MA})$ \\
4 & $4(\mathrm{~B})$ & $3(\mathrm{M})$ & $2(\mathrm{~A})$ \\
5 & $5(\mathrm{MB})$ & $4(\mathrm{~B})$ & $3(\mathrm{M})$ \\
6 & $5(\mathrm{MB})$ & $4(\mathrm{~B})$ & $3(\mathrm{M})$ \\
\hline
\end{tabular}

Legend: 1 (very high MA), 2 (high A), 3 (average M), 4 (low B), 5 (very weak MB).

Table 4. Percentage of classes’ degrees of soil.

\begin{tabular}{ccc}
\hline Classes & Area $\left(\mathrm{Km}^{2}\right)$ & Percentage (\%) \\
\hline 1 Very high (MA) & 0.23 & 0.12 \\
2 High (A) & 1.77 & 0.88 \\
3 Average (M) & 11.4 & 5.70 \\
4 Low (B) & 7.53 & 3.77 \\
5 Very weak (MB) & 179 & 89.53 \\
\hline
\end{tabular}




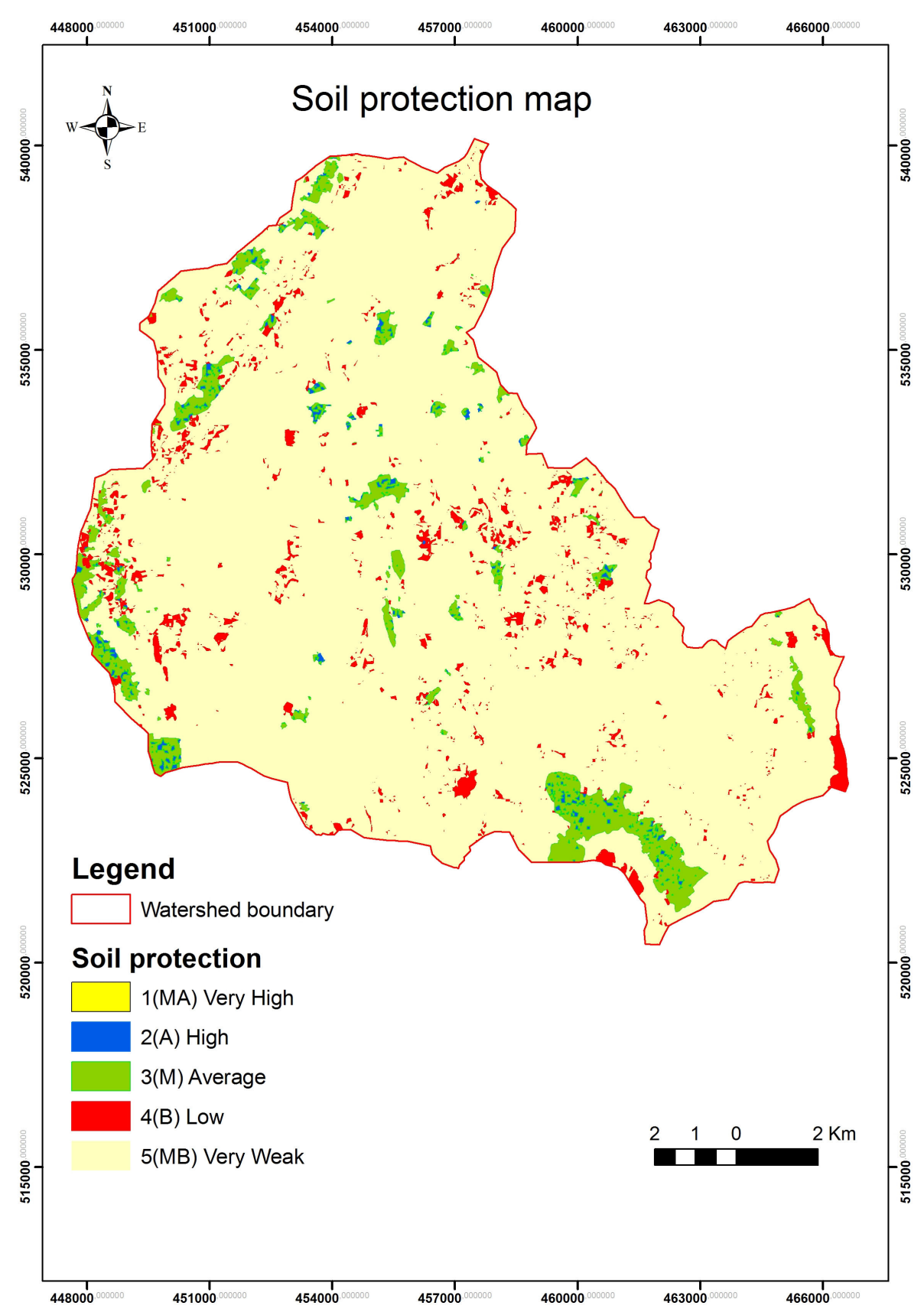

Figure 5. Soil protection map.

Table 5. Matrix soil protection-erodibility.

\begin{tabular}{cccccc}
\hline \multirow{2}{*}{ Degree of soils protection } & \multicolumn{5}{c}{ Degree of erodibility } \\
\cline { 2 - 6 } & $1(\mathrm{EN})$ & $2(\mathrm{~EB})$ & $3(\mathrm{EM})$ & $4(\mathrm{EA})$ & $5(\mathrm{EX})$ \\
\hline $1(\mathrm{MA})$ & 1 & 1 & 1 & 2 & 2 \\
$2(\mathrm{~A})$ & 1 & 1 & 2 & 3 & 3 \\
$3(\mathrm{M})$ & 1 & 2 & 3 & 5 & 5 \\
$4(\mathrm{~B})$ & 2 & 3 & 4 & 5 & 5 \\
$5(\mathrm{MB})$ & 2 & 3 & & & 5 \\
\hline
\end{tabular}

Legend: 1 (very weak), 2 (low), 3 (notable), 4 (high), 5 (very high). 
and analysis of the resulting map (Figure 6) shows that half of the study area (51\%) has a very elevated state of erosion especially in the South-West and North-East part of the basin. In the center, the risk is always limited to quaternary Tensiftiannes terraces. The middle part of the watershed shows largely weak and significant erosion states and respectively occupies $27 \%$ and $20 \%$ of the total area while the most protected areas represent less than 2\% (Figure 7).

\subsection{The Descriptive Approach}

The completion of the map of forms of erosion was done by digitizing thanks to the extension of open Player plugin of Quantum-GIS that connects to Google satellite, with verifications on ground. The resulting map was codified according to the PAP/RAC guidelines, it shows that $91 \%$ of the basin area is known for stripping and sheet erosion (Figure 8). The center of basin is occupied by badlands with a percentage of $0.02 \%$ whereas the

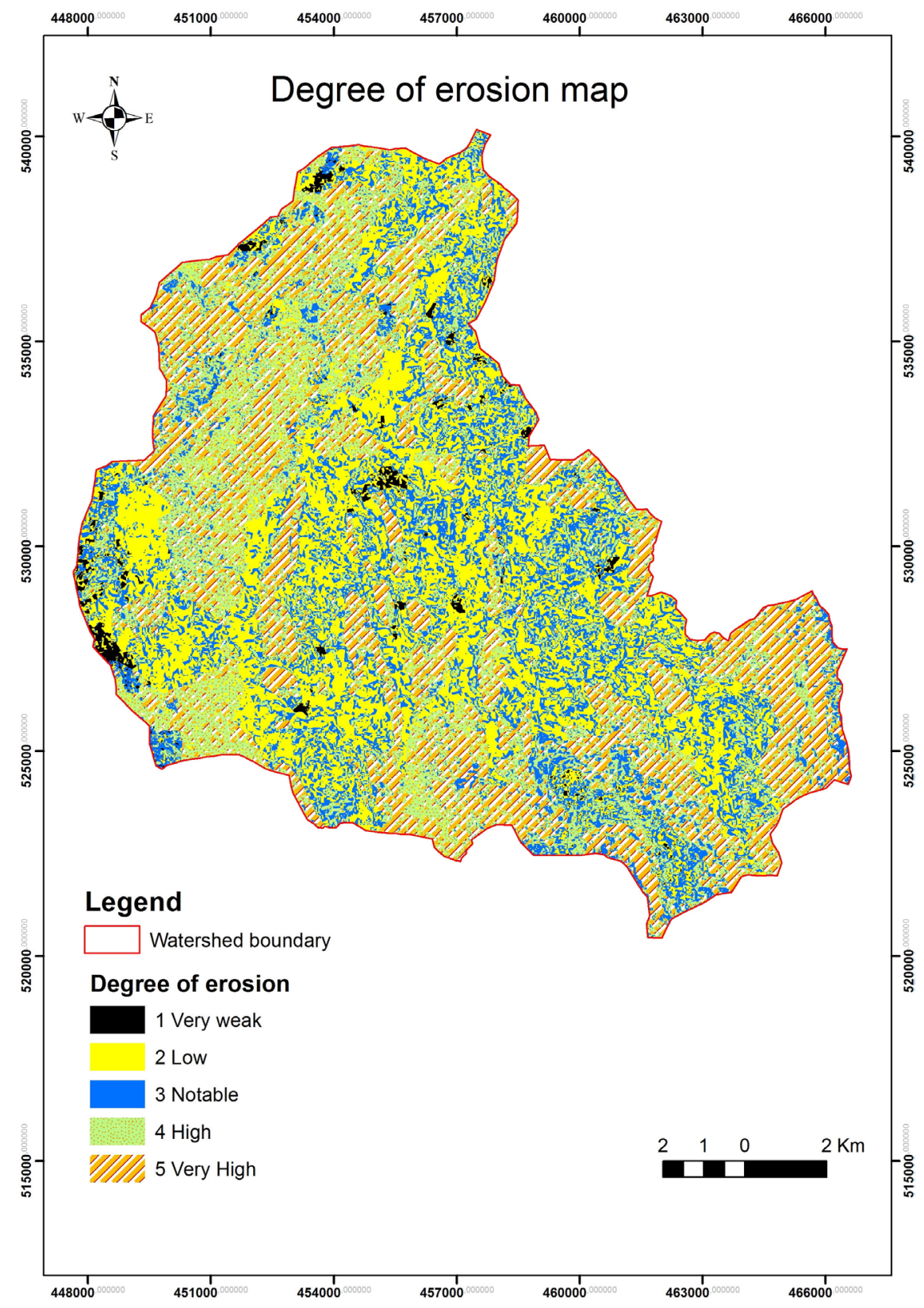

Figure 6. Degree of erosion map. 


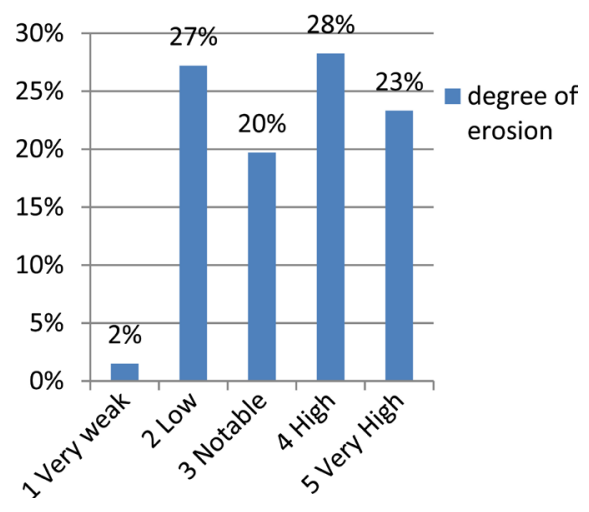

Figure 7. Percentage of classes' degrees of erosion.

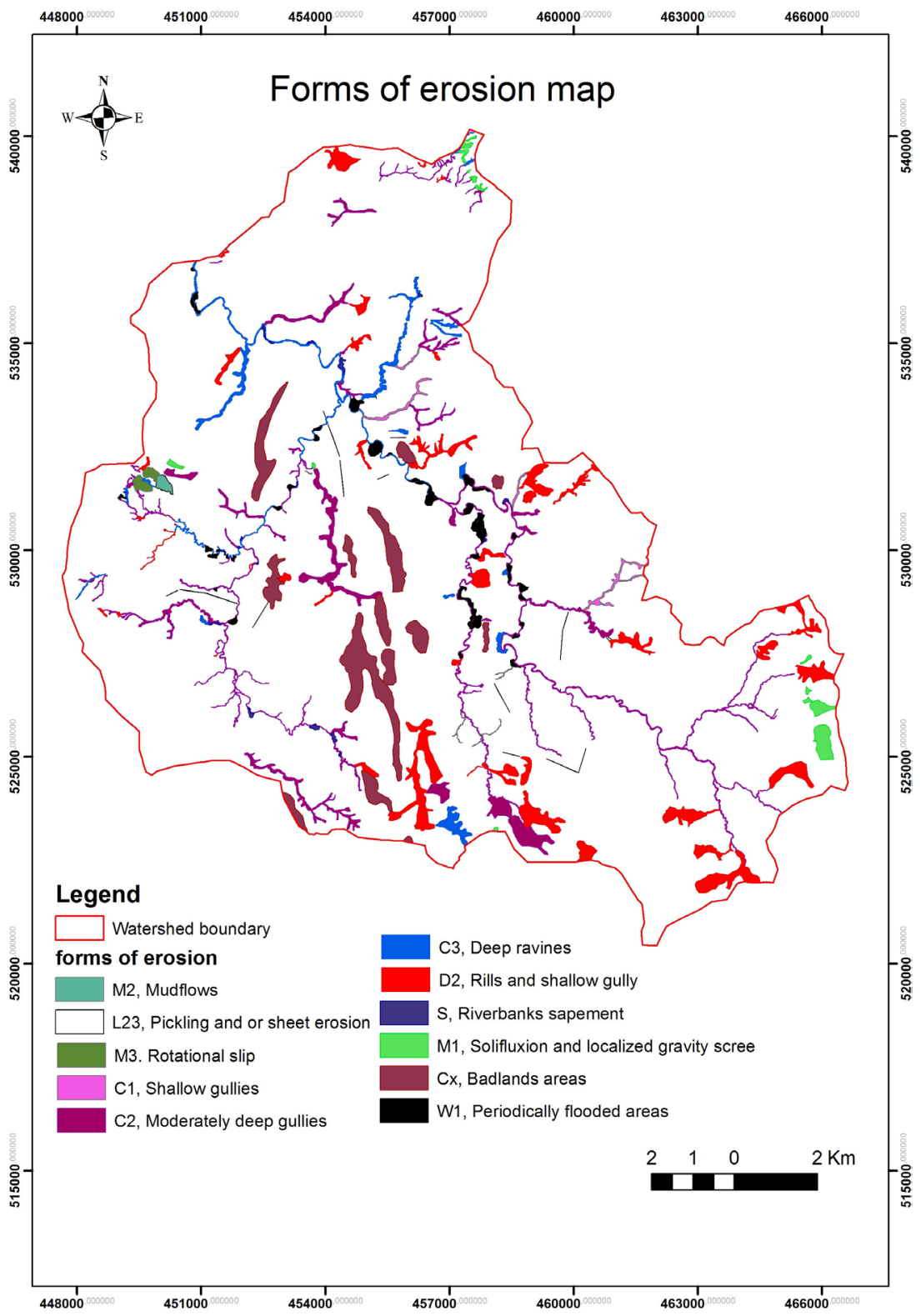

Figure 8. Forms of erosion map. 
rest form of erosion represents only $8.98 \%$ of the area. The analysis of this map shows that all these forms of erosion are related to weather conditions, lithology and the degree of exposure and slopes. It allows making the following remarks:

- In the center of the basin, the fluvial action spawned Tensiftian terrace's that show a raid rim, these terraces become badlands under the action of water erosion factors.

- The upstream part of the basin has shallow ditches and gullies, and to the highest places of the same part, we find solifluxions and located scree of gravity.

- In the upward part of the basin, the ravines increase and turns into moderately deep ravines especially in non-plowed land. This can be explained by the flow of water that grows with the accumulation of precipitations increasing from upstream to downstream. This same phenomenon has been observed in the watershed of Wadi Larbaa, where rill erosion and gullies that if they appear on non-developable land, they generally evolve into larger forms of erosion [6].

- This same ascertainment may explain the abundance of sapements' banks in the downstream of the basin on a large scale, as long as the runoff is accentuated by going to the cavities.

- The shoveling lithology and limestone clay in the eastern basin combined with the strong slopes and the Human action gives rise to mudflows and some rotational slides of field. These forms are located in the northwest of the basin near the village of Olad Yahya where human action is very important.

\subsection{Integration Approach and the Achievement of Consolidated Map PAP/RAC}

The end result of the PAP/RAC method is a map of land degradation states. It is a superposition of thematic maps obtained by the two approaches (Figure 9). The analysis and treatment of this map show that:

- The upstream of watershed, the high erosion coincides with the solifluxions, surface rills and gullies. This same area presents high risks of from one area to another of stripping and slick erosion that are explained by the occupation of the type of soil and the sparse shrubs and pasture that promotes soil loss according to the PAP/CAR guidelines. The significant lower class of erosion in this part of the basin is very small and limited to the entourage of moderately deep ravines. This same observation is made in the watershed of Wadi Larbaa where areas with low and moderate erosion, coinciding the sheet erosion, especially at the edge of the wadi and it are explained by the absence of vegetation cover [7].

- On the cultivated lands, the ditches and shallow gullies are cleared by plowing [8], but on non-plowed areas, they operate in deep ravines promoting significant losses.

- In the center of the basin, very high risks are limited to the areas in which the badlands correspond to tensiftian quaternary terraces with friable nature and which have high altitudes.

- In the downstream of the basin, the evolutionary gullies' trend makes this area more propitious to high soil losses. This effect is combined with the extension of soils, with high erodibility and which are slightly developed, and to the steep slopes and to the absence of dense vegetation.

\section{Conclusions}

The watershed area of the river Arbaa Ayacha is a favorable environment for the development of water erosion risks due to its morphological characteristics, climate and land use.

The map of erosive states shows that more than half of the basin is subject to very high risks, and this increase in soil loss shows good correlation of the major factors controlling the erosive process.

These same factors are at the origin of the development of forms of erosion with predominance of stripping and sheet erosion. The latter is considered to be the most dangerous vis-à-vis the soil since it causes a depletion of the fine fraction particles and nutrients.

The consolidated map PAP/RAC provides the evolutionary trend of the watershed. The heavy losses in land values coincide with extreme degrees of involvement of each factor controlling the water erosion. It is consistent with the most replied forms of erosion in the area in question (deep and moderately deep ravines, gullies and badlands). The brittle and lithological nature of badlands that match the Tensiftian terraces, combined with its high altitudes, make the center of the basin more exposed to soil losses from one place to another.

Faced with these threats of land degradation, the Arbaa Ayacha watershed is a site that requires an urgent response to future plans, especially with the installation of the dam planned in Arbaa Ayacha, and the implementation of the PAP/RAC guidelines is necessary for planners and policy makers, especially when it is conjugated 


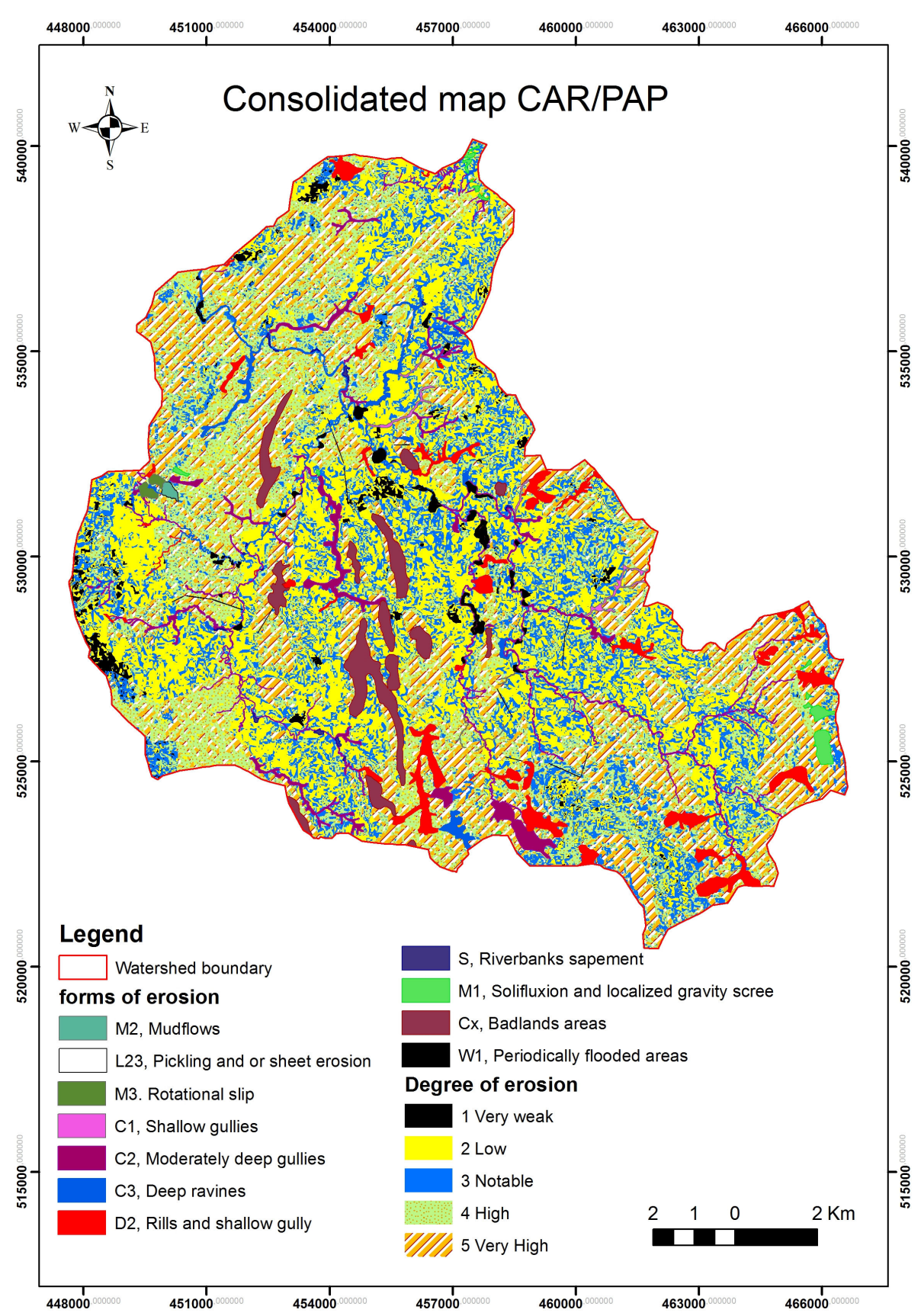

Figure 9. Consolidated map PAP/RAC.

to other models and techniques of quantitative and qualitative studies of water erosion.

\section{Acknowledgements}

We would especially like to thank and express our appreciation to the staff of the DREFLCD-SEAP Rif, for the comments and discussions successful that helped improve this work.

\section{References}

[1] PAP/RAC (1997) Guidelines for Mapping and Measurement of Rainfall-Induced Erosion Processes in the Mediterranean Coastal Areas. PAP-8/PP/GL.1. Split, Priority Actions Programme Regional Activity Centre (PAM/PNUE), in 
Collaboration with FAO, xii+72. www.pap-thecoastcentre.org/pdfs/SoilErosioneng.pdf

[2] Mesrar, H., Sadiki, A. and Navas, A. (2014) Modélisation de l'érosion hydrique et étude des facteurs causaux "cas de l'oued Sahla, Maroc”. Proceeding of SAWIS, No. 01.

[3] El Gharbaoui, A. (1981) La Terre et l’Homme dans la Péninsule Tingitane. Essai sur l'Homme et le milieu naturel dans le Rif occidental. Travaux de l’Institut Scientifique, Série géologie et géographie physique, No. 15, Rabat.

[4] ABHL (2012) Projet du plan directeur intègre des ressources en eau des bassins du loukkos, du tangerois et cotiers méditerranéens. Agence des bassins hydraulique du Loukkous (ABHL), 54.

[5] Sadiki, A., Bouhlassa, S., Auajjar, J., faleh, A. and Macaire, J.J. (2004) Utilisation d'un SIG pour l'évaluation et la cartographie des risques d'érosion par l'Equation universelle des pertes en sol dans le Rif oriental (Maroc): Cas du bassin versant de l'oued Boussouab. Bulletin de l'Institut Scientifique, Rabat, Section Sciences de la Terre, No. 26, 69-79.

[6] Sadiki, A., Mesrar, H. and Faleh, A. (2012) Modélisation et cartographie des risques de l'érosion hydrique: Cas du bassin versant de l'oued Larbaa, Maroc. Papeles de Geografia, 55-56, 179-188.

[7] Faleh, A. and Maktite, A. (2014) Cartographie des zones vulnérables à l'érosion hydrique à l'aide de la méthode PAP/ CAR et SIG en amont du barrage Allal el fassi, moyen Atlas (Maroc). Papeles de Geografia, 59-60, 71-82. http://dx.doi.org/10.6018/geografia/2014/218161

[8] Sadiki, A., Faleh, A., Zêzere, J.L. and Mastass, H. (2009) Quantification de l'érosion en nappes dans le bassin versant de l’oued Sahla, Rif central Maroc. Cahiers Géographiques nº/2009, 59-70.

[9] Tahouri, J., Karrat, L. and Mesrar, H. (2016) Utilisation du modèle PAP/RAC et des outils SIG pour la cartographie et l'evaluation des processus d'érosion hydrique en milieu méditerranéen cas du bassin versant de l'oued Asfalou-Maroc. https://www.academia.edu/22181609/

[10] INYPSA (1987) Etude des sols au 1/100.000 (Edition au 1/50.000). Projet Intégré de développement Agricole de Tanger-Tétouan, Secteur de Tétouan. Inypsa-Maroc, S.A. et Direction Provinciale de l'Agriculture de Tétouan.

[11] Osrirhi, A., El Oumri, M., Moussadek, R., Moatamid, Z., Ambri, A. and Goebel, W. (2007) Vocation agricole des terres de la province de Tanger-Rapport et cartes. Rapport-Institut National de la Recherche Agronomique. www.inra.org.ma/environ/docs/cvat/tanger/tanger.pdf

[12] Purevdorrj, T., Tateishi, R., Ishiyama, T. and Honda, Y. (1998) Relationships between Percent Vegetation Cover and Vegetation Indices. International Journal of Remote Sensing, 19, 3519-3535.

http://dx.doi.org/10.1080/014311698213795

\section{Submit or recommend next manuscript to SCIRP and we will provide best service for you:}

Accepting pre-submission inquiries through Email, Facebook, Linkedin, Twitter, etc

A wide selection of journals (inclusive of 9 subjects, more than 200 journals)

Providing a 24-hour high-quality service

User-friendly online submission system

Fair and swift peer-review system

Efficient typesetting and proofreading procedure

Display of the result of downloads and visits, as well as the number of cited articles

Maximum dissemination of your research work

Submit your manuscript at: http://papersubmission.scirp.org/ 